\title{
EKSEKUSI BENDA MILIK PIHAK KETIGA KETIKA DEBITUR WANPRESTASI (Studi di PT Pegadaian Cabang Nganjuk)
}

\author{
Windy \\ E-mail: rahmandaagustia@gmail.com \\ Mahasiswa Fakultas Hukum Universitas Sebelas Maret \\ Pranoto \\ E-mail: maspran7@gmail.com \\ Dosen Fakultas Hukum Universitas Sebelas Maret
}

\begin{abstract}
This article aims to know when the debtor does not inform the third party if the goods will be made collateral and then the debtor is tort. This article belongs to the type of empirical research that is descriptive to provide data that is likely to be about human, state or other symptoms with a qualitative approach. The data used is primary data and secondary data. Data collection techniques using data collection tools such as document study or library material, observation or observation, and interviews or interview. The results showed that the execution of the goods owned by third party debtor in PT. Nganjuk Pawn Branch can be done by parate execution, ecsekutorial title and sales under hand by means of selling pawn objects is carried out publicly according to local customs and customary requirements, which in practice in its implementation is carried out after maturity of 120 days or 4 months from the date of credit.
\end{abstract}

Keywords: Pawnshop; Pawn Object Execution; Tort

\begin{abstract}
Abstrak
Artikel ini bertujuan untuk mengetahui ketika debitur tidak memberitahu terlebih dahulu kepada pihak ketiga jika barangnya akan dijadikan jaminan gadai dan kemudian debitur tersebut wanprestasi. Artikel ini termasuk ke dalam jenis penelitian empiris yang bersifat deskriptif untuk memberikan data yang seteliti mungkin tentang manusia, keadaan atau gejala-gejala lainnya dengan pendekatan kualitatif. Data yang digunakan merupakan data primer dan data sekunder. Teknik pengumpulan data menggunakan alat pengumpulan data yaitu studi dokumen atau bahan pustaka, pengamatan atau observasi, dan wawancara atau interview. Hasil penelitian menunjukkan bahwa Eksekusi Benda Gadai Milik Pihak Ketiga Debitur Wanprestasi Pada PT Pegadaian Cabang Nganjuk dapat dilakukan dengan parate eksekusi, titel eksekutorial dan penjualan bawah tangan dengan cara melakukan penjualan benda gadai adalah dilakukan di hadapan umum menurut kebiasaan setempat dan persyaratan yang lazim, yang pada praktiknya dalam pelaksanaannya dilaksanakan setelah jatuh tempo 120 hari atau 4 bulan dari tanggal kredit.
\end{abstract}

Kata Kunci: Pegadaian; Eksekusi Benda Gadai; Wanprestasi

\section{A. Pendahuluan}

Manusia sebagai makhluk sosial, yaitu makhluk yang selalu hidup dalam masyarakat, senantiasa memerlukan adanya bantuan-bantuan dari manusia yang lain yang bersama-sama dalam memenuhi kebutuhan kehidupannya dalam bermasyarakat. Dalam hal ini, manusia selalu berhubungan satu sama lain baik disadari atau tidak, untuk selalu mencukupi kebutuhan dalam hidupnya (Ahmad Azhar Basyir, 2000 : 11). Ketika terjadi kekurangan dana, masyarakat dapat menyiasati hal tersebut dengan melakukan peminjaman uang (Shintya Robiatul Adawiyah dkk, $2018: 156)$. 
Pemerintah Indonesia memberikan sarana berupa perbankan maupun non-perbankan untuk mempermudah masyarakat dalam memperoleh dana pinjaman. Salah satu lembaga non perbankan yang menyediakan kredit adalah PT Pegadaian yang sebelumnya merupakan Perusahaan Umum Pegadaian (Perum Pegadaian). PT Pegadaian merupakan sebuah Badan Usaha Milik Negara (BUMN) yang kegiatan utamanya menyalurkan uang pinjaman atas dasar hukum gadai, dalam rangka membantu masyarakat yang berpenghasilan rendah (Mariam Darus Badrulzaman, 1987 : 72). Oleh karena itu, PT Pegadaian berusaha memberikan pelayanan terbaik untuk masyarakat (Rahmadi Usman, 2001 : 52). suku bunga pinjaman yang berbentuk kredit mikro (kecil), berdasarkan kondisi tersebut saat itu PT Pegadaian lebih dari sekedar sarana alternative tempat peminjaman uang (Joni Oktavianto Dkk, 2016 : 3)

Perjanjian gadai, akan ditentukan beberapa klausul-klausul yang memuat kesepakatan mengenai hutang piutang antara para pihak dalam hal ini pihak yang memberikan jaminan gadai disebut sebagai pemberi gadai atau debitur sedangkan pihak lain yang menerima jaminan gadai disebut sebagai penerima gadai dapat pula disebut sebagai kreditur. Akan tetapi tidak menutup kemungkinan bahwa atas persetujuan para pihak benda gadai dipegang oleh pihak ketiga sebagaimana yang telah dijelaskan dalam Pasal $1152 \mathrm{KUH}$ Perdata maka pihak ketiga tersebut disebut sebagai pihak ketiga pemegang gadai. Begitu pula dalam hal pihak yang memberikan jaminan gadai, jika debitur sendiri yang memberikan jaminan, maka ia disebut sebagai debitur pemberi gadai sedangkan jika benda jaminan adalah milik dan diberikan oleh pihak ketiga, maka di sana ada pihak ketiga pemberi gadai (J. Satrio. 1993 : 90).

Akan tetapi beberapa persoalan yang sering terjadi khususnya di Nganjuk adakalanya debitur yang meminjam dana pada PT Pegadaian yang justru menjaminkan benda milik pihak ketiga sebagai jaminan pinjaman debitur itu sendiri dan tidak sedikit dari debitur-debitur tersebut terkadang melakukan wanprestasi terhadap perjanjian gadai yang telah disepakati dengan tidak membayar atau melunasi pinjaman tepat pada waktunya. Sesuai dengan ketentuan yang ada penerima atau pemegang gadai yang bertindak sebagai kreditur dalam hal ini pihak PT Pegadaian berhak untuk menjual barang gadai meskipun benda milik pihak ketiga sebagai penulasan atau pinjaman tersebut sebagaimana telah ditentukan dalam Pasal 1150 KUH Perdata yakni PT Pegadaian diberi kewenangan untuk mengambil pelunasan dari barang gadai, yakni dengan melakukan parate eksekusi (Gunawan Widjaya dan Ahmad Yani. 2001 : 88). Hal ini menjadi menarik untuk dibahas, ketika seorang debitur melakukan gadai dengan menjaminkan barang milih pihak ketiga. Di dalam menjaminkan barang milik pihak ketiga, seorang debitur bisa saja sudah mendapat ijin dari pihak ketiga dan melakukan perjanjian. Namun bagaimana jika debitur tidak memberitahu terlebih dahulu kepada pihak ketiga jika barangnya akan dijadikan jaminan gadai dan kemudian debitur tersebut wanprestasi.

Dalam artikel ini penulis akan membahas mengenai bagaimana eksekusi benda gadai milik pihak ketiga debitur wanprestasi pada PT Pegadaian cabang Nganjuk.

\section{B. Metode Penelitian}

Artikel ini termasuk ke dalam jenis penelitian empiris. Sifat penelitian yang digunakan yaitu penelitian deskriptif untuk mempertegas hipotesa agar dapat membantu dalam memperkuat teori-teori lama atau di dalam kerangka menyusun teori-teori baru (Soerjono Soekanto, 2010:11). Pendekatan penelitian yang digunakan dalam penelitian ini adalah pendekatan kualitatif. Jenis data yang akan digunakan penulis dalam penelitian ini adalah data primer yaitu data yang diperoleh secara langsung dari sumber pertama atau melalui penelitian lapangan yaitu melalui wawancara untuk memperoleh keterangan dari pihak-pihak yang terkait dengan permasalahan yang diteliti dan data sekunder yang diperoleh atau didapat dari keterangan atau pengetahuan-pengetahuan yang diperoleh secara tidak langsung antara lain mencakup dokumen-dokumen resmi, buku-buku, hasilhasil penelitian yang berwujud laporan (Soerjono Soekanto, $2010: 12$ ). Teknik analisis data dengan teknik analisis dan kualitatif dengan menggunakan, mengelompokkan, dan menyeleksi data yang 
diperoleh dari penelitian lapangan, kemudian dihubungkan dengan teori-teori, asas-asas, dan kaidah-kaidah hukum yang diperoleh dari studi kepustakaan.

\section{Hasil Penelitian dan Pembahasan}

Wanprestasi dalam hukum perikatan dapat diartikan sebagai suatu kelalaian atau ingkar janji, bentuk wanprestasi itu adalah tidak melakukan prestasi sama sekali, melaksanakan prestasi tetapi hanya sebagian, melaksanakan prestasi tetapi terlambat, melaksanakan prestasi namun tidak sebagaimana mestinya. Menurut Pasal 115 KUHPerdata menyatakan sebagai berikut:

"Apabila oleh para pihak tidak telah diperjanjikan lain, maka si berpiutang adalah berhak jika si berutang atau si pemberi gadai bercedera janji setelah tenggang waktu yang ditentukan lampau, atau jika tidak telah ditentukan suatu tentang waktu, setelah dilakukannya suatu peringatan untuk membayar, menyuruh menjual barang gadainya, di muka umum menurut kebiasaan-kebiasaan setempat serta atas syarat-syarat yang lazim berlaku, dengan maksud untuk mengambil pelunasan jumlah piutangnya beserta bunga dan biaya dari pendapatan penjualan tersebut". Jika barang gadainya terdiri atas barang-barang perdagangan atau efekefek yang dapat diperdagangkan di pasar atau di bursa, maka penjualannya dapat dilakukan di tempat-tempat tersebut, asal dengan perantaraan dua orang makelar yang ahli dalam perdagangan barang-barang itu."

Debitur yang meminjam dana pada PT Pegadaian Cabang Nganjuk yang justru menjaminkan benda milik pihak ketiga sebagai penjaminan pinjaman debitur itu sendiri dan tidak sedikit dari debitur-debitur tersebut terkadang melakukan wanprestasi terhadap perjanjian gadai yang telah disepakati dengan tidak membayar atau melunasi pinjaman tepat pada waktunya. Mengeksekusi barang jaminan jika debitor wansprestasi, yaitu dengan parate eksekusi, titel eksekutorial dan penjualan bawah tangan. Pilihan yang dirasakan paling efisien bagi kreditor yaitu parate eksekusi. Hal ini dikarenakan jika dilakukan eksekusi di bawah tangan, maka sering terjadi permasalahan di kemudian hari dan jika eksekusi dilakukan dengan titel eksekutorial, walaupun prosesnya lebih ringkas daripada gugatan perdata di pengadilan, akan tetapi tetap saja melibatkan Pengadilan dengan mengindahkan proses Hukum Acara Perdata tentang eksekusi dan akan memakan waktu dan biaya. Dengan demikian parate eksekusi merupakan bentuk eksekusi yang paling mudah dan sederhana untuk mempercepat pelunasan piutang kreditor dibandingkan dengan bentuk eksekusi yang lain, karena kreditor pemegang hak jaminan tersebut dapat menjual objek jaminannya atas kekuasaan sendiri.

Berdasarkan hasil wawancara pada hari Selasa, 4 Mei 2019 dengan saudara Adin sebagai wakil dari Kepala Kantor PT Pegadaian Cabang Nganjuk juga menyatakan bahwa:

"Adanya kasus, dimana nasabah yang menggadaikan dengan menggunakan jaminan benda milik pihak ketiga, kemudian nasabah melakukan wanprestasi. Hal tersebut kemudian langsung dilakukan parate eksekusi atau lelang dengan proses yang sederhana, dimana jika gadai BPKB melakukan wanprestasi akan diberikan somasi 1 (satu) atau surat peringatan selama jangka waktu seminggu selama 3 (tiga) kali, namun tidak ada tanggapan atau tidak mempunyai itikad baik, maka PT Pegadaian Cabang Nganjuk wajib menarik barang jaminannya. Namun eksekusi lelang terhadap Benda Gadai Milik Pihak Ketiga Debitur Wanprestasi . sejauh ini eksekusi dilakukan dengan parate eksekusi."

Permasalahan muncul ketika PT Pegadaian Nganjuk dalam menjalankan fungsi dan tugasnya menawarkan peminjaman dengan sistem gadai. Sistem ini memiliki kemudahan antara lain prosedur dan syarat-syarat administrasi yang mudah dan sederhana. Pemberian jaminan dapat dibedakan atas jaminan dengan menguasai bendanya dan tanpa menguasai bendanya. Dalam hak tersebut maka jika nasabah menggadaikan BPKB mobil, namun PT Pegadaian Nganjuk hanya mengambil 
BPKB saja tanpa adanya penarikan barangnya dan barang tetap ada di nasabah. Proses eksekusi barang gadai milik pihak ketiga ketika nasabah wanprestasi di PT Pegadaian Cabang Nganjuk menurut Adin sebagai wakil dari Kepala Kantor PT Pegadaian Cabang Nganjuk yang beralamat di Jalan Supriyadi Nomor 16, Nganjuk, Jawa Timur menyatakan sebagai berikut:

"Ketika eksekusi dengan jaminan BPKB mobil ada tim mikro dan ada debt collector-nya, jadi langsung tidak dapat membayar kewajiban untuk menarik barang jaminannya yang akan dilunasi, dan biasanya diberi tenggang waktu dengan cara barang disimpan dulu sampai diangsur hingga lunas, dan kebanyakan jika barang sudah diambil nasabah akan segera melunasi, pegadaian nganjuk tidak pernah sampai menjual barang jaminan tersebut, hanya melakukan tindakan persuasive yaitu disimpan saja, jika sudah lunas baru barang bisa dikembalikan. Tenggang waktu tergantung dari kesepakatan nasabah dengan pegadaian, maksimal 3 bulan. Jadi pada intinya pegadaian menunggu nasabah untuk membayar sampai lunas. Untuk menafsirkan harga gadai BPKB motor ditentukan oleh tim mikro merupakan tim yang bertugas untuk memproses permohonan kredit dari nasabah dengan dokumen-dokumen pendukung seperti KTP suami dan istri, BKPB, STNK, Surat Izin Usaha, Kartu Keluarga, Denah lokasi Usaha. Setelah di proses oleh Tim Mikro dengan data-data yang diperlukan lengkap. Proses dimulai dengan meminta data informasi debitur dengan cara melakukan kunjungan ke lokasi usaha (on the spot), wawancara, dan penilaian agunan. Selanjutnya adalah pencairan yang diproses oleh penaksir dan selanjutnya diberikan kepada kasir untuk pencairan uang."

Sesuai dengan ketentuan yang ada penerima atau pemegang gadai yang bertindak sebagai kreditur dalam hal ini pihak PT Pegadaian Cabang Nganjuk berhak untuk menjual barang gadai meskipun benda milik pihak ketiga sebagai penulasan atau pinjaman tersebut sebagaimana telah ditentukan dalam Pasal 1150 KUHPerdata yakni PT Pegadaian diberi kewenangan untuk mengambil pelunasan dari barang gadai, yakni dengan melakukan parate eksekusi.

Berdasarkan hasil wawancara pada hari Jumat, 10 Mei 2019 dengan saudara Adin sebagai wakil dari Kepala Kantor PT Pegadaian Cabang Nganjuk yang beralamat di Jalan Supriyadi Nomor 16, Nganjuk, Jawa Timur bahwa Tindakan yang dilakukan PT Pegadaian (Persero) Cabang Nganjuk apabila debitur wanprestasi adalah sebagai berikut:

"Memberitahukan nasabah bahwa pembayaran kreditnya akan jatuh tempo dengan cara menelepon nasabah kemudian ditindaklanjuti dengan mengirimkan SMS sebanyak 3x. Setelah menunggu selama 1 minggu nasabah tersebut belum juga datang membayar agunan pokok perjanjian kredit beserta bunganya maka pihak PT Pegadaian menyurati nasabah satu persatu yang melakukan wanprestasi. Dengan memakai hak pemegang gadai yang disebut pelaksanaan segera (parate eksekusi), penjualan dengan cara ini yang paling sering dilakukan oleh kantor PT Pegadaian."

Parate eksekusi merupakan bentuk eksekusi yang paling mudah dan sederhana untuk mempercepat pelunasan piutang kreditor dibandingkan dengan bentuk eksekusi yang lain, karena kreditor pemegang hak jaminan tersebut dapat menjual objek jaminannya atas kekuasaan sendiri. Lembaga parate eksekusi ditujukan agar kreditor mendapat kemudahan pelunasan hak tagihnya. Hal ini merupakan konsekuensi dari konsep lembaga jaminan khusus, yang sifatnya memberikan kemudahan dan kedudukan didahulukan bagi kreditur dalam mendapatkan pelunasan hak tagihnya. Sehingga patutlah dipahami bahwa dimasukkannya lembaga jaminan khusus oleh pembuat undang-undang ditujukan semata-mata bagi kepentingan kreditur, karena bila kita melihat pada sisi kepentingan debitur maka lembaga jaminan umum sudah cukup mengakomodir.

Pengaturan parate eksekusi dapat dibagi ke dalam dua bagian, yaitu pengaturan parate eksekusi dalam hipotik dan pengaturan parate eksekusi dalam hak tanggungan. Pengaturan parate eksekusi dalam hipotik diatur dalam Pasal 1178 Ayat (2) Kitab Undang-Undang Hukum Perdata Indonesia yang berbunyi: 
"Namun diperkenankanlah kepada pemegang hipotik pertama untuk, pada waktu diberikannya hipotik, dengan tegas minta diperjanjikan bahwa, jika utang pokok tidak dilunasi semestinya, atau jika bunga hutang tidak dibayar, ia secara mutlak akan dikuasakan menjual persil yang diperikatkan, di muka umum, untuk mengambil pelunasan utang pokok, maupun bunga serta biaya, dari pendapatan penjualan itu. Janji tersebut harus dibukukan dalam register-register umum, sedangkan penjualan lelang harus dilakukan menurut cara sebagaimana diatur dalam Pasal 1211."

Parate eksekusi yang dilakukan terhadap Benda Gadai Milik Pihak Ketiga Debitur Wanprestasi di PT. Pegadian Cabang Nganjuk dilakukan dengan memperhatikan kepastian hukum, kemanfaatan, dan keadilan kepada pihak-pihak yang berkepentingan. Teori kepastian hukum menurut Utrecht mengandung dua pengertian yaitu pertama adanya aturan yang bersifat umum membuat individu mengetahui perbuatan apa yang boleh atau tidak boleh dilakukan, dan kedua, berupa keamanan hukum bagi individu dari kesewenangan pemerintah karena dengan adanya aturan yang bersifat umum itu individu dapat mengetahui apa saja yang boleh dibebankan atau dilakukan oleh Negara terhadap individu (Riduan Syahrini, 1999:23). Sedangkan menurut Gustav Radbruch menyebutkan bahwa teori keadilan ditinjau dari sudut filosofis, dimana keadilan adalah kesamaan hak untuk semua orang dan teori kemanfaatan hukum dimana dapat dikemukakan bahwa summon ius, summa injuria, summa lex, summa crux yang artinya adalah hukum yang keras dapat melukai, kecuali keadilan yang dapat menolongnya, dengan demikian kendatipun keadilan bukan merupakan tujuan hukum satu-satunya akan tetapi tujuan hukum yang substantive adalah keadilan (Dosminikus Rato, 2010:59). Wanprestasi adalah apabila si berhutang (debitur) tidak melakukan apa yang dijanjikannya. la alpa atau lalai atau ingkar janji, atau juga ia melanggar perjanjian (Meitha Djohan Oe, 2012 : 44).

Debitur yang meminjam dana pada PT Pegadaian Cabang Nganjuk yang justru menjaminkan benda milik pihak ketiga sebagai penjaminan pinjaman debitur itu sendiri dan tidak sedikit dari debitur-debitur tersebut terkadang melakukan wanprestasi terhadap perjanjian gadai yang telah disepakati dengan tidak membayar atau melunasi pinjaman tepat pada waktunya. Sesuai dengan ketentuan yang ada penerima atau pemegang gadai yang bertindak sebagai kreditur dalam hal ini pihak PT Pegadaian Cabang Nganjuk berhak untuk menjual barang gadai meskipun benda milik pihak ketiga sebagai pelunasan atau pinjaman tersebut sebagaimana telah ditentukan dalam Pasal 1150 KUHPerdata yakni PT Pegadaian diberi kewenangan untuk mengambil pelunasan dari barang gadai, yakni dengan melakukan parate eksekusi.

Mekanisme eksekusi benda gadai milik pihak ketiga dalam hal debitur wanprestasi pada PT Pegadaian Cabang Nganjuk dengan hasil Adin sebagai wakil dari Kepala Kantor PT. Dengan melakukan parate eksekusi terhadap benda gadai tersebut, jika debitur melakukan wanprestasi terhadap perjanjian kredit yang telah ditandatangani dalam SBK. Cara melakukan penjualan benda gadai adalah dilakukan dihadapan umum menurut kebiasaan setempat dan persyaratan yang lazim, yang pada praktiknya dalam pelaksanaannya dilaksanakan setelah jatuh tempo 120 hari atau 4 bulan dari tanggal kredit.

Berdasarkan penjelasan di atas, maka eksekusi benda gadai milik pihak ketiga debitur yang melakukan wanprestasi pada PT Pegadaian cabang Nganjuk dapat dilakukan dengan dua cara yaitu eksekusi lelang dan parate eksekusi. Namun, sampai saat ini PT Pegadaian cabang Nganjuk belum pernah menerapkan eksekusi lelang pada benda gadai milik pihak ketiga debitur yang wanprestasi. PT Pegadaian cabang Nganjuk saat ini menerapkan parate eksekusi terhadap benda gadai milik pihak ketiga yang melakukan wanprestasi karena dinilai yang paling mudah dan sederhana untuk mempercepat pelunasan pelunasan piutang kreditor dibandingkan dengan bentuk eksekusi yang lain, karena kreditor pemegang hak jaminan tersebut dapat menjual objek jaminannya atas kekuasaan sendiri. Terhadap parate eksekusi yang dilakukan oleh PT Pegadaian cabang Nganjuk dalam pelaksanaannya dilakukan dengan memperhatikan kepastian hukum, kemanfaatan, dan keadilan kepada pihak-pihak yang berkepentingan agar mengetahui perbuatan apa yang boleh atau tidak boleh dilakukan, dan kedua, berupa keamanan hukum bagi individu serta memberikan keadilan bagi para pihak. 


\section{Simpulan}

Uang Gadai Milik Pihak Ketiga Debitur Wanprestasi Pada PT Pegadaian Cabang Nganjuk dapat dilakukan dengan dapat dilakukan dengan memberitahukan nasabah bahwa pembayaran kreditnya akan jatuh tempo dengan cara menelepon nasabah kemudian ditindaklanjuti dengan mengirim SMS sebanyak 3 kali. Setelah menunggu selama 1 minggu nasabah tersebut belum juga datang membayar agunan pokok perjanjian kredit beserta bunganya maka pihak PT Pegadaian menyurati nasabah satu persatu yang melakukan wanprestasi. Namun, jika tidak ada tanggapan dilakukan dengan dua cara yaitu eksekusi lelang atau parate eksekusi. Namun, sampai saat ini PT Pegadaian cabang Nganjuk belum pernah menerapkan eksekusi lelang pada benda gadai milik pihak ketiga debitur yang wanprestasi. PT Pegadaian cabang Nganjuk saat ini menerapkan parate eksekusi terhadap benda gadai milik pihak ketiga dengan proses yang sederhana, dimana jika gadai BPKB melakukan wanprestasi akan diberikan somasi 1 (satu) atau surat peringatan selama jangka waktu seminggu selama 3 (tiga) kali, namun tidak ada tanggapan atau tidak mempunyai itikad baik, maka PT Pegadaian Cabang Nganjuk wajib menarik barang jaminannya yang melakukan wanprestasi karena dinilai yang paling mudah dan sederhana untuk mempercepat pelunasan pelunasan piutang kreditor dibandingkan dengan bentuk eksekusi yang lain karena kreditor pemegang hak jaminan. Terhadap parate eksekusi yang dilakukan oleh PT Pegadaian cabang Nganjuk dalam pelaksanaannya dilakukan dengan memperhatikan kepastian hukum, kemanfaatan, dan keadilan kepada pihak-pihak yang berkepentingan agar mengetahui perbuatan apa yang boleh atau tidak boleh dilakukan, dan kedua, berupa keamanan hukum bagi individu serta memberikan keadilan bagi para pihak.

\section{E. Saran}

Kepada PT Pegadaian Cabang Nganjuk perlu membuat Standar Operasional Prosedur (SOP) untuk memberikan kepastian hukum dalam mengeksekusi benda jaminan milik pihak ketiga.

\section{F. Daftar Pustaka}

Ahmad Azhar Basyir. 2000. Asas-Asas Hukum Muamalat. Ed. Revisi. Yogyakarta : UII Press

Gunawan Widjaya dan Ahmad Yani. 2001. Seri Hukum Bisnis Jaminan. Jakarta: PT Raja Grafindo Persada

J Satrio. 1993. Hukum Jaminan. Hak- Hak Kebendaan. Bandung : PT. Citra Aditya Bakti

Mariam Darus Badrulzaman. 1987. Bab-bab Tentang Creditverban, Gadai, dan Fiducia. Cet. IV. Bandung: Alumni.

Rahmadi Usman. 2001. Aspek-Aspek Hukum Perbankan di Indonesia. Jakarta: PT Gramedia Pustaka Utama

Soerjono Soekanto. 2010. Pengantar Penelitian Hukum. Jakarta : Universitas Indonesia

Joni Oktavianto, R. Suharto, Triyono, 2016 "Tanggungjawab PT Pegadaian (Persero) Atas Kerusakan dan Kehilangan Barang Gadai di PT Pegadaian (Persero) Kota Semarang". Diponegoro Law Journal. Volume 5 Nomor 3.

Meitha Djohan Oe, 2012. "Penyelesaian Sengketa dalam Perjanjian Pembiayaan Konsumen Sebagai Akibat Wanprestasi". Pranata Hokum. Volume 7 Nomor 1. Edisi Januari 2012

Shintya Robiatul Adawiyah, Amnawaty, Dewi Septiana, 2018. "Pelaksanaan Gadai Emas Syariah Sebagai Alternatif Pembiayaan di Kota Bandar Lampung". Pactum Law Jurnal. Volume 1 Nomor 2

Kitab Undang-Undang Hukum Perdata.

Peraturan Pemerintah Nomor 103 Tahun 2000 tentang Perusahaan Umum (PERUM) Pegadaian.

Peraturan Pemerintah Nomor 51 tahun 2011 tentang Perubahan Bentuk Badan Hukum Perusahaan Umum (PERUM) Pegadaian Menjadi Perusahaan Perseroan (PERSERO). 